COLLOQUIA THEOLOGICA OTTONIANA 1/2018, s. 267-278

DOI: $10.18276 /$ cto.2018.1-13

\title{
EMOTIONS IN THE CONTEXT OF THE END OF HUMAN LIFE
}

\author{
Tadeusz Dyk*, Marcin Kolwitz ${ }^{* *}$ \\ Pomorski Uniwersytet Medyczny w Szczecinie
}

\section{Socio-cultural dimension of death}

Death can be described as a state characterized by the absence of the signs of life, which is caused by the irreversible aberration of functional balance and collapse $o$ the inner organization of the system. Commonly accepted in medicine is a definition according to which only the death of the creative brain allows to consider a man as no longer alive ${ }^{1}$ (however, in Poland this definition is called into question by neurosurgeon professor Jan Talar).

Death, as a final stage of sickness is perceived not only as a physical and biological phenomenon but also as social event. Thus, the phenomenon of death is a subject of interest of both sociology of medicine and medical ethics.

From a sociological point of view, death has three dimensions: individual, family and group dimension. Death of a single member of a family impoverishes

* Dr n. hum. Tadeusz Dyk - asystent w Katedrze i Zakładzie Zdrowia Publicznego Pomorskiego Uniwersytetu Medycznego w Szczecinie. Zajmuje się homiletyką, katechetyką, filozofią i socjologią medycyny oraz medycyną społeczną. Zainteresowania naukowe: problemy etyczne w ochronie zdrowia, personalistyczny wymiar samotności. E-mail: tadeuszdyk@interia.pl.

** Dr n. med. Marcin Kolwitz - asystent w Katedrze i Zakładzie Zdrowia Publicznego Pomorskiego Uniwersytetu Medycznego w Szczecinie. Zajmuje się filozofią i socjologią medycyny oraz polityką społeczną i zdrowotną. Zainteresowania naukowe: problemy etyczne w ochronie zdrowia, polski system opieki zdrowotnej, jego wymiar prawno-ekonomiczno-polityczny. E-mail: rutinex@ pum.edu.pl.

1 T. Ślipko, Bioetyka. Najważniejsze problemy, Kraków 2009, s. 428-431. 
not only entire family but it may also have impact on social circles connected to it (neighbors and friends). The group of people connected to the family of a departed person creates mechanisms which are meant to relieve the consequences of the loss (a fear of emptiness and a loss of meaning of life which may appear). These mechanisms also serve to help to accept the death of a closed one and to find oneself in a new situation.

The elements which strengthen the bond within a group in the context of death may be enlisted as follow: listening to the closed ones of a departed person, cultural and religious rites associated to death, such as customary visit or farewell to the dying person, giving the expressions of compassion towards the family, common prayers in the house of the departed. Traditional customs and norms associated to funeral (participation in funeral procession, ringing of church bells), which exist mainly in smaller towns, support the family of the departed person and inform the whole society of the fact of death. In this manner, these signs are reminders of the existence and inevitability of death.

However, attitude towards death has gone through transformation together with the civilization changes. Among them, there need to be indicated: the development of cities and associated to it a change in organization of life; the development in medicine; secularization process; sociological changes associated to a character of a modern family. Contemporary attitudes towards death are described as 'reversed death' or 'death the wrong way round'. This phenomenon is based on the fact that death is driven away from people awareness and is practically absent in the public discourse. The behavioral patterns applied to the situation of death are to deny its existence. The condolences are rarely given; black is not worn as a sign of mourning; prayers in a community are not said. The process of dying happens more often in a hospital than at home and therefore the phenomenon of death becomes more and more distant from the everyday life. Funeral celebrations (especially in the bigger cities) take place mainly in the cemetery and are unnoticeable for the people who do not participate in them. Moreover, also the everyday language describing death is changing. The talks regarding death are more rare; when it is necessary, some substitute terms are in use- a man does not die but departs. Children are isolated from the phenomenon of death, they are not allowed contact with dying people (in the past, such contact was common in multigenerational families). Additionally, also a general cultural transmission is focused on the young and middle-aged people while old age is ignored or seen as something embarrassing (despite the growing number of old people in modern societies). This is another example of pushing the death out of the everyday life. 
Cultural changes had its impact also on the shift in perception of death by the family in relationships with the sick person. It is common to create for the sick an illusion that his state is not as grave as in reality, that he may overcome sickness and avoid death. Also the full information about the diagnosis is not given. The coming death is often something even surprising, perceived as an error in medical treatment- a technical error. Deepening of such thinking may cause numerous court processes and accusations against the hospital and medical staff ${ }^{2}$.

Consequently, the shift in a paradigm of death has its consequences in the difficulties in accepting death, the abilities to talk about death and so in the communication patient- patient's family - doctor.

The second factor causing communication difficulties is a classic form of hospital functioning in which a priority is always given to actions of a scope of restorative medicine. Thus, hospitals are often unprepared to realize tasks deriving from the care of dying person. Such situation is a result of a shortage of qualified personnel (psychologists) as well as the lack of psychosocial skills among the doctors and nurses.

The above mentioned difficulties lead to the conclusion that it is necessary to determine mechanisms of introducing the terminally ill person in the process of dying. To work out such mechanisms, there is a strong need for an awareness of emotional states of the sick, as well as of his environment, which are associated to the appearing perspective of death.

\section{The stages of accepting the diagnosis of death}

A proposal of a model depiction of a process of communication and accepting emotions associated to death by the patients and their families is the conception of the stages of dying described by Elizabeth Kubler-Ross. This conception refers to traumatic events in human life and is based on natural defensive reactions of a person experiencing different form a loss.

The first phase of negation and isolation is an emotional reaction of a patient for message about the terminal illness. Most often, the words are: 'No, it is not possible, it is not me...'. Such behavior may be a defensive form against the arduousness of illness as well as against the perspective of the coming end. It is a reaction to a shock which may lead to the breaking of the entire present world of the ill person.

2 I. Taranowicz, Z. Kawczyńska-Butrym, Śmierć jako zjawisko społeczne, w: Elementy socjologii dla pielęgniarek, red. I. Taranowicz, A. Majchrowska, Z. Kawczyńska-Butrym, Lublin 2000, s. 261-262. 
As the phase of a shock passes and the ill person starts to regain psychological balance, the patient begins to deny facts: 'No, it does not apply to me'. In this phase the sick person negates coming information and expresses disagreement of the situation. He does not believe in the results of medical examinations, he insists to repeat them. Negative results, according to the sick, are a consequence of the fail medical apparatus or they are mistakenly assigned to a wrong person. The sick person looks for denial of diagnosis by going to other doctors. Sometimes he talks about his sickness but in a way that demonstratively trivializes it.

A fear and lack of support may cause a deepening of isolation of the sick, his complete withdrawal from the everyday life and abstaining from any duties. It may even lead to the breaking of any human relationships. The attitude of denial may take different levels of intensity and it may occur not only after the diagnosis but also in the later stages.

After the phase of denial the most frequent emotional states are: anger, rebellion, rage, jealousy. Articulations of these feelings are grievances against medical personnel, family or God. Doctors, according to the sick (and his family) made a mistake putting the diagnosis too late; moreover, they are helpless in finding solutions which would save the life of the sick. Carers are too little emphatic, they perform their duties in a routine way and treat the patient as an object.

A family is accused by the sick of the rare visits and caring about their own interests. Finally, the same reactions are addressed to God, who disappointed the sick and cannot be called a God of love if he allows people to suffer. Thus, the anger of the sick on that stage find its proper outlet.

During that phase, the sick begins to envy others their health. The questions come: 'Why me of all people?' Similar questions are asked by the closed ones of the sick: 'Such a good man. Why him?' Formulation of such questions may mirror emotional states of the sick as well as of his family.

The next stage is bargaining, which is an attempt to postpone death. The sick takes an attitude which might be described as doing trade. It is an element of the so-called natural religiosity ('if God decided to take me from this earth, maybe he would listen to me if I ask and offer something in return'). And so, the patient bargains with God, promising good deeds in order to achieve healing. Most frequently, the sick desire to prolong their life without sufferings and physical ailments. These desires take form of petitions: 'May I see my child passing the final exam', 'Lord God, stop the sickness, and I promise that I will regularly go to church'. Sometimes, the sick openly desire to make a deal with a hospital (in reality, with God), promising to offer their body for scientific objectives, if only doctors used the most modern medical procedures to prolong the life of the sick. The phase of 
bargaining with God normally happens in secret. Sometimes, the patient confesses it to a priest or other close person ${ }^{3}$.

When the fact of death and being terminally ill becomes undeniable and indisputable for the sick, the symptoms intensify and the sick enters the next stagedepression. Its first symptoms may occur already in the first phase. Depression is normally accompanied by the feeling of guilt (sickness is a punishment) and the lack of will to fight the illness. The sick person avoids contact with others and does not expect consolation from anyone. Depression may have 'reactive' or 'preparatory' character. 'Reactive' depression is a reaction to the symptoms of illness and inability to fulfill social roles (e.g. a parent, a spouse, family carer). On the other hand, 'preparatory' depression is associated with the preparations of the sick for the moment of death. Only after having overcome depression, the sick may enter the last stage of acceptance of his illness. Not everyone is able to overcome depression (that is why the last stage is not achieved by all the terminally ill). A patient who has accepted the perspective of death does not feel any more broken or angry because of his destiny. He awaits the moment of death with helplessness but calmly. This stage may be characterized by emotions of helplessness and loss mainly among the close ones of the sick. That is why the family may require more psychological and spiritual help than the dying person himself. The length and the intensity of singular phases of terminal illness may vary among the patients. They are always dependent on individual dispositions and character of a person, as well as on the individual value system, religion and faith (they mainly have impact on the occurrence of the last stage).However, in all of these stages the sick may manifest symptoms of fear and terror. Such emotions may be expressed through words, aggressive behavior, or silence ${ }^{4}$. The knowledge of consecutive emotional reactions within described phases is helpful for the sick as well as his environment and medical personnel in appropriate reaction to the phenomenon of death. It may lead to acceptance of the coming death.

\section{Communication in process of dying}

The obligation of a doctor, and his everyday experience, is giving information to the patient about the state of his health. Despite the fact, that already Hippocrates

3 E. Kubler-Ross, Rozmowy o śmierci i umieraniu, tłum. I. Doleżal-Nowicka, Warszawa 1979, s. $43-52$.

4 H. Wrona-Polańska, Psychologiczne aspekty informowania pacjentów o chorobie, w: Psychologiczny wymiar zdrowia, kryzysu i choroby, red. D. Kubacka-Jasiecka, T.M. Ostrowski, Kraków 2005, s. 87-89. 
in his deontological recommendations warned to tell patients about doctor's diagnosis, the dilemma remains actual: how and when inform the patient about his sickness.

In building positive relationships between the sides of the dialogue: doctorpatient and his family, crucially important is the rule of truthfulness. It is also necessary to estimate the scope of information which the patient should obtain. The person giving this information should take into account not only the current state but also the age and education of the sick.

Communication of the bad news about sickness obliges the doctor to absolutely respect the principle of not leaving the person on his own with the awareness of the coming death. Showing understanding and respect towards the sick, and most of all empathy, may have influence on going through the subsequent stages of sickness. A person giving the information about prognosis should aim to find the so called golden mean- not to deprive the sick of hope, but at the same time not to give a vain hope. Mechanization and bureaucratization of medicine as well as domination of paternal model in relationship doctor-patient may cause inappropriate communication of the information about terminal sickness to the sick and his family (e.g. in the hospital corridor).

Doctor's conduct while giving the bad news might be divided into several stages. First of all, it is necessary to find out what information about sickness the patient already possesses and how much he desires to know in this specific moment. It should be remembered that during the process of sickness the patient may change his attitude in regards to obtaining these information.

The next stage is the actual communication of the bad news and confronting the patient's reaction to the information. It should consists in revealing patient's feelings, showing full understanding, empathy and readiness to support the patient, as well as demonstrating one's own emotions.

The last phase is the final confrontation with the problem, searching for optimal solutions, indicating consequences which derive from the situation and planning further actions. The person communicating the news should give to the patient some time to get accustomed to the news and come back to the subject after a couple of days. Due to emotional shock which 'paralyzes' the patient, he is not able to absorb any more information.

In communicating bad information it should be taken into account that verbal message is accompanied by non-verbal signals. The place and situation in which the message is given is also important. It should not be communicated in the presence of other people from medical staff or patients. The environment should ensure intimacy- it could be consulting room or house of the sick person. 
Patient's mood should be fine and his physical state without intensive pain. The dialogue itself should be performed without rush in a calm atmosphere (both persons sitting), giving to the sick all the attention and time required. Eye contact should be maintained.

To relieve emotions and tension associated to the end of life it is important to have a sincere talk with the sick about his situation. The doctor should encourage questions. Among the common mistakes are: giving hasty advices, minimalizing feelings of the patients, routine calming, asking about patient's mood or usage of a medical jargon. Moreover, it is not recommended to give imprudent answers to the questions such as 'How long will I live? How much time do I have? Am I dying yet?' It is necessary to convince the sick and his family about the limits of diagnosis: 'As a doctor, I am not able to answer precisely when the death comes'. It ought to be kept in mind that the first task of medical care is a patient assistance given to the sick, a help in revealing his emotions, showing understanding, giving hand throughout all stages of the illness, and not giving verdicts 5 .

No less significant is the way of communication with a minor patient. The leading doctor should communicate to the child basic information about his sickness and therapeutic process. Attentive listening to the child's opinion would allow adjusting the language to the patient's personal situation. The doctor should be for the parents not only a reliable source of knowledge about the state of their child but also a source of support. If the child, observing the contact, grows in conviction that his parents trust the doctor, the anxiety in the child diminishes. If the parents remain distrustful towards the doctor, also the child is unwilling to make the contact with him. The conversation with a child should not only brake the barrier but also allow to get to know the child's opinion about his health state, his mood and other possible problems. Only in the atmosphere of trust such conversation may take place. The dialogue should be adjusted to the age and intellectual level of the child so that it would allow to recognize possible negative emotions. Estimation of the emotional state of the child allows to choose an appropriate strategy in transmitting further information. It is said that the doctor should not communicate the entire information in case of terminal illness, not to deprive the child of hope for recovering. He should rather create an illusion of favorable future. It is caused by the fact that terminal illness may create a feeling of alienation, of being unable to fulfill one's role. It may also happen that the child pretends to show that

5 M.M. Bujnowska-Fedek, I. Wróblewska, Przekazywanie pacjentowi i jego rodzinie złych $i$ trudnych informacji dotyczacych stanu zdrowia, w: Porozumiewanie się lekarza z pacjentem i jego rodzina. Wybrane zagadnienia, red. A. Steciwko, J. Barański, Wrocław 2012, s. 163-167. 
his emotional state is not bad. Such pretending may lead to the situation when the child is not properly listened to, and does not receive the help he deserves ${ }^{6}$.

However, sometimes a prolonged sickness impacts a greater maturity of the child, who may be more prepared to accept the brutal truth about his sickness and coming death than his parents.

The information about a grave illness is normally very difficult for the family and the close ones of the patient. It influences the mutual relationship between the environment and the dying person in the last stage of the sickness. This relationship may be characterized by certain artificiality and hypocrisy. It often happens that the close ones of the sick do not know how to behave and what to talk about. They thriftily hide their true feelings: fear and sadness. It is also difficult to the patient, who realizes the truth.

The interactions between the dying person and his environment may be divided into four types, depending on the awareness of death: a closed awareness, suspicions, mutual pretending, an open awareness.

A model of closed awareness refers to the situation, in which the sick is not aware of his state of health. Such knowledge has the environment of the sick, who keeps the sick unaware.

This model may be transformed into the model of open awareness, also called a model of suspicions. We talk about suspicions when the family and medical personnel attempt to keep the diagnosis secret, but the patient suspects that he is terminally ill. He tries in different ways to discover the truth that is kept hidden from him.

A model of common pretending occurs when both sides know about the coming death but pretend that 'nothing is happening'. The subjects which could disturb this silent agreement are avoided in a conversation.

Finally, a model of open awareness is a situation in which the death is outright spoken of. The sick, his family and medical personnel all know about the coming death. Death and dying are not the taboo anymore. It is considered to be the most advantageous situation for both sides of the interaction?

The attitude of the medical personnel, the patient and his family is influenced by the attitudes of all the subjects, but the attitude of the family is important. As the closest to the patient's knowledge of the sickness, he can decide how to respond to the sickness. Can accept the truth to limit it or even avoid it.

6 A.K. Jankowska, Postępowanie z dzieckiem i jego opiekunami. Porozumiewanie się z nastolatkiem, w: Porozumiewanie się lekarza z pacjentem i jego rodziną..., s. 83-91.

7 A. Ostrowska, Śmierć w doświadczeniu jednostki i społeczeństwa, Warszawa 1997, s. 146. 
The smallest possible influence on the model of mutual relations may be possessed by the patient, due to the natural limitations associated with the sickness. They may concern the limitations of consciousness that affect perception in perceiving one's state of health.

These limits are least relevant to people dying from cancer. This group of patients usually has full awareness about their health and inevitably imminent death. There are several reasons for this awareness. First of all, changes in the body are so pronounced (manifested) that patients can have no doubt not only about the development of the sickness, but also its ultimate outcome. In addition, the progression of fatal cancers, usually occurring at certain slow stages (the disease is not sudden), can therefore be seen by all the symptoms. It is also important that cancer often affects people in the age of strength, with a clear mind, and a great ability for perception and self-observation. Full awareness of cancer patients causes these people to usually go through all the stages of dying described by Elizabeth Kubler-Ross. So they are the most complete "field of observation" of the subsequent stages of dying.

\section{Summation}

The achievements of modern medicine introduced a new quality in a traditional understanding of death. Technological development allowed to effectively limit or eliminate illnesses which were before regarded as the terminal ones.

On the other hand, because of the cultural changes that occurred, the subject of death is omitted or pushed to the background of everyday life. Before, death were treated in a fatalistic manner, as a common fate and destiny of the human race. It caused reflection. Currently, even the threat of a helpless illness not always prompts to prepare oneself for death. Tendencies to stop and push away the inevitability of death are the result of a natural human anxiety and fear associated to death. Realizing his own weakness, experiencing disappointment, frustration of unfulfilled dreams and fear of the inevitable, in the same time a man aims for homeostasis, and so for life ${ }^{9}$. That is why accepting the truth about the coming end of life may be really difficult.

8 J. Brehant, Thanatos. Chory i lekarz w obliczu śmierci, thum. U. Sudolska, Warszawa 1993, s. 112.

9 M. Komorska, Postawy wobec śmierci - wybrane zagadnienia, w: Szkice z socjologii medycyny, red. M. Libiszowska-Żółtkowska, M. Ogryzko-Wiewiórowska, W. Piątkowski, Lublin 1998, s. 207. 
Beside avoiding the truth about the coming death in the relationship between the sick and his family, another problem that may occur is the lack of communication skills among the medical personnel. These problems may be reduced thanks to the doctor's ability to communicate the difficult diagnosis. Such skill should be the result of both knowledge (gained during the studies but also specialized courses) and empathy, which is indispensable element of the call to be a doctor. It seems necessary then, to enlarge in the process of medical education the role of subjects, such as sociology of medicine and medical psychology, which would allow to gain psychosocial skills.

A significant factor is self-awareness of the patient and his family, as well as mentioned before doctor's knowledge of the emotional states associated to death as experienced by the sick. Such awareness should be accompanied by the attitude of sincerity and acceptance of the difficult truth about the coming death. To face, and even to accept this truth, it is necessary to find a firm fundament connected to the value system, e.g. believe in the afterlife. This faith allows not only to possess the hope of a possible health improvement (in medicine, the cases are known where the recovery cannot be rationally explained), but it may also help to see the meaning of death as the final stage of illness.

\section{Bibliography}

Brehant J., Thanatos. Chory i lekarz w obliczu śmierci, thum. U. Sudolska, Warszawa 1993.

Bujnowska-Fedek M.M., Wróblewska I., Przekazywanie pacjentowi i jego rodzinie złych i trudnych informacji dotyczacych stanu zdrowia, w: Porozumiewanie się lekarza z pacjentem i jego rodzina. Wybrane zagadnienia, red. A. Steciwko, J. Barański, Wrocław 2012.

Jankowska A.K., Postępowanie z dzieckiem i jego opiekunami. Porozumiewanie się $z$ nastolatkiem, w: Porozumiewanie się lekarza z pacjentem i jego rodzina. Wybrane zagadnienia, red. A. Steciwko, J. Barański, Wrocław 2012.

Komorska M., Postawy wobec śmierci - wybrane zagadnienia, w: Szkice z socjologii medycyny, red. M. Libiszowska-Żółtkowska, M. Ogryzko-Wiewiórowska, W. Piątkowski, Lublin 1998.

Kubler-Ross E., Rozmowy o śmierci i umieraniu, tłum. I. Doleżal-Nowicka, Warszawa 1979.

Ostrowska A., Śmierć w doświadczeniu jednostki i społeczeństwa, Warszawa 1997.

Ślipko T., Bioetyka. Najważniejsze problemy, Kraków 2009. 
Taranowicz I., Kawczyńska-Butrym Z., Śmierć jako zjawisko społeczne, w: Elementy socjologii dla pielęgniarek, red. I. Taranowicz, A. Majchrowska, Z. Kawczyńska-Butrym, Lublin 2000.

Wrona-Polańska H., Psychologiczne aspekty informowania pacjentów o chorobie, w: Psychologiczny wymiar zdrowia, kryzysu i choroby, red. D. Kubacka-Jasiecka, T.M. Ostrowski, Kraków 2005.

\section{EMOCJE ZWIĄZANE Z KOŃCEM LUDZKIEGO ŻYCIA}

\section{Streszczenie}

W konsekwencji przemian kulturowych i postępu technologicznego w medycynie we współczesnych społeczeństwach nastąpiła zmiana postrzegania śmierci. Staje się ona coraz częściej tematem tabu. Jednocześnie cały czas pojawiają się trudności komunikacyjne w relacjach na płaszczyźnie umierający pacjent - otoczenie - personel medyczny. Rozwiązanie wspomnianych trudności jest możliwe dzięki umiejętnościom przekazania przez lekarzy diagnozy bolesnej dla pacjenta i jego rodziny oraz jej przyjęcia przez zainteresowanych. Niezbędne we wzajemnej komunikacji wszystkich uczestników procesu leczenia (także pracowników medycznych, chorego i jego rodziny) jest świadomość naturalnych reakcji psychosocjologicznych związanych z przyswajaniem traumatycznych wydarzeń, takich jak śmierć, oraz nieunikanie prawdy o śmiertelnej chorobie.

Slowa kluczowe: relacja, choroba, lekarz, rodzina 


\title{
EMOTIONS IN THE CONTEXT OF THE END OF HUMAN LIFE
}

\begin{abstract}
Summary
As a consequence of cultural changes and technological progress in medicine, in nowadays societies there has been a shift in perception of death. Death becomes more often a taboo. At the same time, there are still difficulties in communication in relationship: dying patient- his environment- medical personnel. The solution of the difficulties mentioned above is possible thanks to certain skills: communication of a painful diagnosis by the doctors to the patient and his family as well as its acceptance by all the involved. It is crucial for all the participants of healing process (medical personnel, as well as the sick person and his family) to have awareness of natural psycho- and sociological reactions to traumatic events such as death. It is also necessary not to avoid the truth about the deadly sickness.
\end{abstract}

Keywords: relationship, sickness, doctor, family 